Ann. Biol. anim. Bioch. Biophys., 1977, 17 (3 A), 389-391.

\title{
Role of the follicle in zona pellucida maturation of hamster oocyte
}

\author{
par Jacqueline MANDELBAUM *, Michèle PLACHOT **, C. THIBAULT *** \\ * Service d'Endocrinologie et de Gynécologie médicale, Hôpital Necker, 151, rue de Sèvres, 75015 Paris \\ ** Laboratoire de Cyłogénétique, Hôpital Necker, 151, rue de Sèvres, 75015 Paris \\ *** Physiologie de la Reproduction, Université de Paris VI, I.N.R.A., 78350 Jouy-en-josas, France.
}

It has been shown in many mammalian oocytes that in vivo maturation includes both nuclear and cytoplasmic aspects. Hamster occytes matured in vitro are not fertilizable (Mandelbaum and Plachot, 1977). When immature oocytes are fertilized after zona removal, male pronucleus formation does not occur normally, i.e. the sperm head penetrates into the egg cytoplasm but does not swell (Usui and Yanagimachi, 1976). In this report, we re-investigate hamster oocyte maturation, comparing extraand intrafollicular maturations.

\section{Material and methods.}

In all experiments, cycling females received 30 IU of PMSG at day 1. Part of the females were killed $48 \mathrm{hrs}$ later, and the largest follicles or their oocytes isolated and cultured in suitable media : oocytes in the $\mathrm{GH}_{2}$ medium of Gwatkin and Haidri (1973) supplemented with tubal or follicular fluid, and follicles in HAM or TC 199 supplemented or not with fetal calf serum, hamster serum, chicken embryo extract, gonadotropins or ovarian steroids.

Intrafollicular oocyte culture requires high oxygen tension, either by increased pressure or with 56 p. 100 oxygen to avoid granulosa pyknosis.

The rest of the females received 30 IU of HCG 48 to $54 \mathrm{hrs}$ after the initial injection of PMSG ; they were killed at increasing times (from 2 to $15 \mathrm{hrs)}$ ) after injection.

Oocytes were collected either in preovulatory follicles, cultured in vitro until complete maturation and then fertilized, or collected in the tubes and fertilized directly.

Modified Bavister's fertilization procedure (Whittingham and Bavister, 1974) was employed, and in all experiments the same sample of epididymal sperm was used on experimental and tubal control oocytes. 


\section{Results.}

\section{Extrafollicular oocytes.}

In a first group of experiments we tried to fertilize extrafollicularly-matured oocytes. 90 p. 100 of the oocytes from PMSG-stimulated follicles resumed meiosis up to metaphase II when cultured for $14 \mathrm{hrs}$ in $\mathrm{GH}_{2}$. When epididymal spermatozoa were added to this medium supplemented with tubal or follicular fluid, no fertilization occurred (0/58), while 80 p. 100 of the control oocytes were fertilized by the same sperm sample. There was no change when FSH and LH or $17 \beta$-estradiol and progesterone were added to the maturation medium.

Contrary to observations in rabbit (Thibault and Gérard, 1970), we did not observe any spermatozoon penetration through the zona pellucida. In hamster, the zona pellucida seems to be involved in the complete maturation process.

Combined in vivo and in vitro maturation shows that fertilizability is acquired if oocytes remain in their follicles at least $6 \mathrm{hrs}$ after HCG injection :

$<6$ hours 3 fertilizations with 75 oocyles $=4$ p. 100

6 hours 15 fertilizations with 56 oocytes $=27$ p. 100

$>6$ hours 10 fertilizations with 15 oocytes $=66$ p. 100 .

Intrafollicular oocyfes.

In a second group of experiments, we tried to fertilize oocytes matured in vitro in their follicles. The largest follicles collected $48 \mathrm{hrs}$ after PMSG treatment were cultured for 11 to $16 \mathrm{hrs}$ in presence of FSH and LH ; 27 out of 40 oocytes reached metaphase 11 (70 p. 100). The number of matured oocytes augmented with increasing amounts of FSH and $\mathrm{LH}$. $(10 \mu \mathrm{g} / \mathrm{ml}$ of $\mathrm{LH}$ and $10 \mu \mathrm{g} / \mathrm{ml}$ of FSH represent optimal doses).

When $17 \beta$-estradiol was added to the gonadotropins, 15 out of 24 oocytes reached metaphase II (63 p. 100) : Estradiol did not seem to enhance gonadotropin action in vitro when added simultaneously.

Thirty oocytes having the first polar body were mixed with epididymal sperm ; 13 were fertilized (43 p. 100) when examined 16 to $24 \mathrm{hrs}$ later. They presented the usual criteria for fertilization, i.e. extrusion of the second polar body and presence of two pronuclei in the egg cytoplasm. The sperm tail and mid-piece, which soon disappear after fertilization, were not recognizable.

\section{Conclusion.}

A new aspect of oocyte maturation has been demonstrated. When nuclear maturation of hamster oocyte occurs in vitro, zona pellucida is not penetrable by spermatozoa. In vivo, this aptitude is acquired $6 \mathrm{hrs}$ or more after HCG injection. When preovulatory follicles are cultured in vitro in presence of gonadotropins, complete oocyte maturation is obtained and fertilization occurs normally. 
Résumé. Lorsque l'ovocyte de hamster est cultivé hors de son follicule la reprise de la méīose se produit normalement, mais l'ovocyte n'est pas fécondable : des spermatozoïdes capables de féconder des ovocytes fraîchement ovulés ne traversent pas sa membrane pellucide.

En prélevant des ovocytes à des temps croissants après administration de HCG à des femelles prétraitées par PMS, on constate que les ovocytes deviennent fécondables $6 \mathrm{~h}$ après l'injection de HCG, donc environ $6 \mathrm{~h}$ avant l'ovulation.

Lorsque des follicules prélevés sur des femelles prétraitées par PMS sont cultivés en présence de FSH et de LH, les ovocytes reprennent leur méïose ; ils peuvent être pénétrés par les spermatozoïdes et fécondés. Le mécanisme qui permet au follicule d'assurer cet aspect particulier de la maturation de l'ovocyte du hamster est inconnu.

\section{References}

MANDELBAUM J., PLACHOT M., 1977. Infécondabilité de l'ovocyte de hamster ayant fait sa maturation in vitro. C. R. Acad. Sci., Paris série D, 284, 953-955.

GWATKIN R. B. L., HAIDRI A. A., 1973. Requirements for the maturation of hamster oocytes in vitro. Exp. Cell Res., 76, 1-7.

THIBAULT C., GÉRARD M., 1970. Facteur cytoplasmique nécessaire à la formation du pronucleus mâle dans l'ovocyte de lapine. C. R. Acad. Sci., Paris série D, 270, 2025-2026.

USUI N., YANAGIMACHI R., 1976. Behavior of hamster sperm nuclei incorporated into eggs at various stages of maturation, fertilization and early development. J. Ultrastruct. Res., 57, 276 288.

WHITTINGHAM D. G., BAVISTER B. D., 1974. Development of hamster eggs fertilized in vitro or in vivo. J. Reprod. Fert., 38, 489-492. 